\title{
Feeding behavior of early weaned lambs deprived of roughage
}

\author{
Miroslav Simeonov ${ }^{1 *}$, Krum Nedelkov², Nadiya Bozakova ${ }^{3}$ \\ ${ }^{1}$ Department of "Preservation, Quality Evaluation and Utilization of Forage Crops" Research Institute of Forge Crops, ${ }^{2}$ Department of Livestock, \\ Faculty of Veterinary Medicine, Trakia University, ${ }^{3}$ Department of Applied Ecology and Zoohigiena, Faculty of Veterinary Medicine, Trakia University
}

\section{A B S T R A C T}

\begin{abstract}
The aim of the present study was to trace the feeding behavior of early weaned lambs deprived of roughage compared with lambs that were fed alfalfa hay ad libitum. The results showed that lambs deprived of roughage intake $10 \%$ more concentrated feed, compared to the animals of the second group, which received alfalfa hay. The lambs intake $12.5 \%$ more feed, compared to the animals deprived of roughage. The lambs deprived of roughage made fewer attempts to feed $(P<0.05)$, which has reduced the total time for eating by $94.8 \mathrm{~min}$, compared to the animals receiving alfalfa hay $(\mathrm{P}<0.01)$. The lambs in the group receiving alfalfa hay had $38.9 \%$ more ruminating periods, compared to the animals deprived of roughage, which has an insignificant influence on the total ruminating time. Deprived of roughage the lambs ruminate the intake dry matter (DM) faster, which affects the shorter chewing time (feeding and ruminating). The number of feedings in lambs deprived of roughage showed a high positive correlation $(P<0.01)$ with the time of consuming $1 \mathrm{~kg}$ of $\mathrm{DM}$ and a high negative correlation with the DM intake speed $(P<0.05)$. There was a linear effect between lying down ruminating in lambs receiving alfalfa hay, significant in lambs deprived of roughage, with the results being significant at $(P<0.01)$. An increased locomotor activity (standing up and playing) was established in the hours around noon, when our observations were conducted. Light was the most intensive around noon and the temperature in the room was the highest.
\end{abstract}

Keywords: Alfalfa; Feeding behavior; Feed intake; Lamb; Roughage; Ruminating

\section{INTRODUCTION}

Feeding behavior of the lambs is characterized by multiple periods of action influenced by food intake, rumination, chewable, inaction (Penning et al., 1991). These actions depend on the kind and physical from of feed and are described "major factors" which in turn may depend on other factors such as the number of the animals in a group (Leme et al., 2013). It is known that feeding area and aggression between animals in the group influences the feeding behavior (Huzzey et al., 2006). This is often referred to as the competition between animals, which reduces feed intake and growth (Norouzian and Vatandoost, 2011). The occurrence of competition between animals is not always have a negative character as group feeding can increase feed consumption and improved the social behavior between animals in the group. According to O'connell et al. (2004) and Titto et al. (2010) the outcome of these group interactions often depends on number for the animals in the group. Feeding behavior is characterized through the duration (the time) of eating, rumination and break - time not eating (Penning et al., 1991) and is used as an indicator of the physical and chemical characteristics of the feed (Lee et al., 2008).

Feed intake is an important fact for economic performance and profitability in growing animals. Pires et al. (2001) stated that individual animals respond differently to different kinds of feed. Polat et al. (2013) found that increasing the neutral detergent fiber and moisture in the roughage reduces the frequency of feeding, feed consumption and increases the break time. According to Dulphy et al. (1980) the inclusion of a large amount of concentrated feed in diet reduces the time for rumination.

Feeding behavior is also influenced by the quality of the feed, which affects the consumption (Keskin et al., 2004). Keskin et al. (2010) recommend providing fresh feed at least three times a day. Feeds given frequently in small amount stimulates consumption, which according to Shabi

\footnotetext{
*Corresponding author:

Miroslav Simeonov, Department of "Preservation, Quality Evaluation and Utilization of Forage Crops" Research Institute of Forge Crops, Pleven, 5800 Bulgaria. E-mail: msimeonov78@abv.bg. Tel: +359/878 632 156. Fax: +359 / 64805881

Received: 05 May 2015; $\quad$ Revised: 09 November 2015; $\quad$ Accepted: 16 November 2015; Published Online: 16 November 2015
} 
et al. (1999), leads to higher degradation of organic matter in dairy cows.

Times of the day, combined with the temperature, also affect feeding behavior. However, alone the time can-not be used as an indicator of feed consumption (Pinto et al., 2010). When temperature is elevated eating decreases the lambs during the period from 12 to 16 hours when the temperature is higher than remainder of the day (Keskin et al., 2010).

The aim of the present study was to trace the feeding behavior of early weaned lambs deprived of roughage compared with lambs that were fed alfalfa hay ad libitum.

\section{MATERIALS AND METHODS}

The study was conducted at the Institute of Forage Crops in the town of Pleven, in February 2011, with 12 early weaned lambs of the Blackhead Pleven Breed. The lambs were weaned with a live weight of $9.261 \mathrm{~kg}$ at the age of 19.6 days (Simeonov, et al, 2015). Following the weaning, the animals were distributed into two groups (6 animals per group), equalised in terms of the parameters of live weight, age, sex and type of birth (single or twins). The animals in each group were distributed into three subgroups (2 lambs in each) and accommodated within boxes with dimensions $3 \mathrm{~m} \times 1.5 \mathrm{~m}$, that is sufficient to to their free movement, feeding and lying. The feeder and the drinker in boxing were constructed so as to allow daily cleaning, washing and disinfection. Parameters of temperature and relative air humidity premises were: $17^{\circ} \mathrm{C}$ (norm from 15 to $17^{\circ} \mathrm{C}$ ) and a relative air humidity $-65 \%$ (norm from 60 to $75 \%$ ), the rate of air movement was: $0.2 \mathrm{~m} / \mathrm{s}-$ in winter (norm to $0.2 \mathrm{~m} / \mathrm{s}$ ).

The concentration of ammonia in premises was $5 \mathrm{mg} / \mathrm{m}^{3}$ (norm to $10 \mathrm{mg} / \mathrm{m}^{3}$ ). Front for the feeding a lamb was $-0.25 \mathrm{~m}$, and front for drinking $-0.03 \mathrm{~m}$. It was natural lighting with luminous coefficient 1:10, at night artificial lighting with an intensity $15-16 \mathrm{~lx}$ (norm from 15 to $16 \mathrm{~lx}$ ). The noise level was $25 \mathrm{~dB}$ (norm to 50 ).

During experimental period, the lambs of the first group were deprived of roughage (alfalfa hay), and animals from the second group received alfalfa hay freely. The lambs of both groups received pelleted protein concentrate (PPC) and wheat at a ratio 1:1 freely. The experimental period had a duration of 66 days, up until reaching $26 \mathrm{~kg}$ of live weight for each animal.

During the experimental period, video recording of the lambs' feeding behaviour (feeding, ruminating, lying down and standing, plus playing) was conducted for four consecutive days, from 8:00 AM to 8:00 PM, in order to encompass the 12-hour light part of the day, at an average live weight $15.7 \mathrm{~kg}$. For this purpose, the animals were numbered with alkyd paint on their backs, which facilitated the individual tracking and registration of feeding behaviour (feeding, ruminating, lying down and standing, plus playing). Throughout the period of observation, the amount of feed intake was registered for both groups of lambs. The feeds were given to the lambs 3 times a day (in the morning at 8:00 AM, at noon at 12:00 AM, and in the afternoon at 4:00 PM). On the grounds of the video recordings and the time measurement of the separate stages of feeding - feed intake, ruminating, lying down, standing and playing, as well as the average amount of feed intake (respectively, dry matter), the time for intake and the time for ruminating $1 \mathrm{~kg}$ of dry matter were calculated on the basis of grams of intake DM for 1 minute and the influence of the intake $\mathrm{DM}$ on the duration of ruminating.

The amount of feed intake, respectively energy and nutrients, is indicated in Table 1 and Table 2.

Pearson's correlation was calculated with the software application Statistica for Windows (2006). The significance among the groups was calculated via the t-test, with the differences being significant at $\mathrm{P}<0.05$ and $\mathrm{P}<0.01$.

Table 1: Content of experimental rations

\begin{tabular}{lcc}
\hline Feeds & $\begin{array}{c}\text { Group 1 } \\
\text { Without roughage }\end{array}$ & $\begin{array}{c}\text { Group 2 } \\
\text { With alfalfa hay }\end{array}$ \\
\hline Alfalfa hay $(\mathrm{g})$ & - & $0.210(20.9 \%)$ \\
PPC $(\mathrm{g})^{*}$ & $0.322(36.5 \%)$ & $0.355(35.4 \%)$ \\
Wheat $(\mathrm{g})$ & $0.560(63.5 \%)$ & $0.439(43.7 \%)$ \\
Total feed intake $(\mathrm{g})$ & 0.882 & 1.004 \\
Feed intake in dry matter $(\mathrm{g})$ & 0.775 & 0.886 \\
\hline
\end{tabular}

*Pelleted protein concentrate

Table 2: Chemical composition and energy contents of experimental feeds

\begin{tabular}{lcc} 
Chemical composition & $\begin{array}{c}\text { Group 1 } \\
\text { Without } \\
\text { roughage }\end{array}$ & $\begin{array}{c}\text { Group 2 } \\
\text { With alfalfa } \\
\text { hay }\end{array}$ \\
\hline Dry matter (g) & 878.5 & 882.7 \\
Feeding units for growth* & 1.203 & 1.184 \\
Crude protein (g) & 153.2 & 174.6 \\
Protein digestible in intestine (g) & 89.9 & 101.3 \\
Protein balance in the rumen (g) & 13.8 & 39.6 \\
Crude fibre (g) & 47.4 & 104.3 \\
Crude fats (g) & 14.7 & 16.8 \\
Mineral substances (g) & 39.0 & 53.8 \\
Calcium (g) & 3.894 & 6.281 \\
Phosphorus (g) & 4.891 & 4.971 \\
\hline
\end{tabular}

*1 Feed units for growth=6 MJ NE 


\section{RESULTS}

Throughout the observation period, the lambs deprived of roughage intake 10\% more concentrated feed, compared to the animals of the second group, which received alfalfa hay (Table 1). The alfalfa hay represented only $20.9 \%$ of the total amount of intake feed in the second group, which is the reason why they intake $12.5 \%$ more feed, compared to the animals deprived of roughage (Table 1).

Lambs deprived of roughage made fewer attempts to feed $(\mathrm{P}<0.05$, Table 3$)$, which has reduced the total time for eating by $94.8 \mathrm{~min}$, compared to the animals receiving alfalfa hay $(\mathrm{P}<0.01$, Table 3$)$. The speed of feed intake was greater in lambs deprived of roughage, yet the duration of feeding was significantly lower (Table 3).

The lambs in the group receiving alfalfa hay had $38.9 \%$ more ruminating periods, compared to the animals deprived of roughage, which has an insignificant influence on the total ruminating time. Deprived of roughage, the lambs ruminate the intake DM faster, which affects the shorter chewing time (feeding and ruminating). In this case, depriving the lambs of roughage was the reason why they spent $206.7 \mathrm{~min}$ less chewing $(\mathrm{P}<0.01)$, which increased the intake of $\mathrm{DM}$ and the speed of chewing it, yet decreased the time necessary for feeding and ruminating by $191.5 \mathrm{~min}(\mathrm{P}<0.01$, Table 3$)$.

The number of feedings in lambs deprived of roughage showed a high positive correlation $(\mathrm{r}=0.930, \mathrm{P}<0.01)$ with the time of consuming $1 \mathrm{~kg}$ of $\mathrm{DM}$ and a high negative correlation with the DM intake speed $(r=-0.887, \mathrm{P}<0.05$, Table 4). In the lambs of the same group moderate negative correlation between the number of feedings and the total ruminating time and the time of intake and ruminating the intake DM was observed $(\mathrm{P}<0.05$, Table 4). Such dependencies were not observed in the animals from the second group, which received alfalfa hay. In both groups of lambs, the feeding time had a very high positive correlation with the time of intake $1 \mathrm{~kg}$ of $\mathrm{DM}(\mathrm{P}<0.01)$, a very high negative correlation with the rate of $\mathrm{DM}$ intake $(\mathrm{P}<0.01)$ and a high negative one with the duration of one ruminating period $(\mathrm{P}<0.05$, Table 4$)$.

The number of ruminating periods in lambs deprived of roughage had a very high negative correlation with DM

Table 3: Feeding behaviour of lambs

\begin{tabular}{|c|c|c|c|}
\hline Parameters & $\begin{array}{c}\text { Group } 1 \\
\text { Without roughage }\end{array}$ & $\begin{array}{c}\text { Group } 2 \\
\text { With alfalfa hay }\end{array}$ & Significance \\
\hline Number of meals per $12 \mathrm{~h}$ & $28.7 \pm 3.018$ & $41.7 \pm 2.179$ & ** \\
\hline Time spent feeding, $\min$ & $113.8 \pm 12.268$ & $208.6 \pm 16.157$ & ** \\
\hline Time for intake of $1 \mathrm{~kg} \mathrm{DM}(\mathrm{min})$ & $146.8 \pm 15.829$ & $235.4 \pm 19.522$ & ** \\
\hline Speed of intake (g DM/min) & $6.8 \pm 0.702$ & $4.2 \pm 0.489$ & * \\
\hline Duration of meal (min) & $4.0 \pm 0.190$ & $5.0 \pm 0.521$ & NS \\
\hline Number of ruminating periods & $10.2 \pm 1.778$ & $16.7 \pm 1.358$ & * \\
\hline Total time spent ruminating (min for $12 \mathrm{~h}$ ) & $144.5 \pm 31.751$ & $256.4 \pm 20.659$ & * \\
\hline Duration of 1 ruminating period (min) & $14.2 \pm 1.131$ & $15.3 \pm 1.465$ & NS \\
\hline DM intake $(\mathrm{g}) /$ ruminating $(\mathrm{min})$ & $5.4 \pm 0.397$ & $3.5 \pm 0.284$ & * \\
\hline Total time spent chewing (feeding+ruminating) (min for 12 hours) & $258.3 \pm 23.398$ & $465.0 \pm 26.782$ & ** \\
\hline DM intake $(\mathrm{g}) /$ chewing duration $(\mathrm{min})$ & $3.0 \pm 0.297$ & $1.9 \pm 0.126$ & ** \\
\hline Time necessary for intake and ruminating of $\mathrm{kg} / \mathrm{DM}(\mathrm{min})$ & $333.3 \pm 30.190$ & $524.8 \pm 30.228$ & ** \\
\hline
\end{tabular}

${ }^{*} P<0.05 ;{ }^{* *} P<0,01 ;$ NS: Not significant

Table 4: Correlations between the feeding behaviour of lambs, depending on the number and time of feedings

\begin{tabular}{|c|c|c|c|c|}
\hline \multirow[t]{2}{*}{ Feeding behaviour } & \multicolumn{2}{|c|}{$\begin{array}{c}\text { Group } 1 \\
\text { Without roughage }\end{array}$} & \multicolumn{2}{|c|}{$\begin{array}{c}\text { Group } 2 \\
\text { With alfalfa hay }\end{array}$} \\
\hline & NF & FT & NF & FT \\
\hline Time for intake $1 \mathrm{~kg} \mathrm{DM}$, min & $0.930^{* *}$ & $1.000^{* *}$ & 0.509 & $1.000^{* *}$ \\
\hline Rate of intake (g DM/min) & $-0.887^{\star}$ & $-0.985^{\star *}$ & -0.386 & $-0.981^{*}$ \\
\hline Feeding duration (g DM/min) & -0.200 & 0.170 & 0.023 & $0.870^{*}$ \\
\hline Number of ruminating periods & -0.762 & -0.720 & 0.293 & 0.624 \\
\hline Total ruminating time (min for 12 hours) & $-0.852^{*}$ & -0.785 & -0.620 & -0.364 \\
\hline Ruminating period duration (min) & -0.923 & $-0.836^{*}$ & -0.749 & $-0.775^{*}$ \\
\hline DM intake, g/ruminating (min) & $0.875^{*}$ & $0.857^{*}$ & 0.629 & 0.328 \\
\hline Total chewing time (min) & -0.669 & -0.540 & 0.018 & 0.696 \\
\hline DM intake $(\mathrm{g}) /$ chewing duration (min) & 0.659 & 0.550 & 0.061 & -0.652 \\
\hline Time necessary for intake and ruminating of $\mathrm{kg} / \mathrm{DM}(\mathrm{min})$ & -0.669 & -0.540 & 0.018 & -0.696 \\
\hline
\end{tabular}

NF: Number of feedings; FT: Feeding time, min; ${ }^{*} \mathrm{P}<0.05$; ${ }^{* *} \mathrm{P}<0.01$ 
intake and the duration of its chewing $(\mathrm{P}<0.01$, Table 5). The total chewing time and the time required for intake and ruminating had a very high positive correlation with the number of ruminating periods $(\mathrm{P}<0.01)$, while in lambs receiving alfalfa hay, this dependency was high $(\mathrm{P}<0.01$, Table 5).

The total time of ruminating periods in the lambs deprived of roughage had a very high negative correlation with the number of feedings, the time for intake and ruminating of the DM, as well as with intake DM and the duration of chewing it $(\mathrm{P}<0.01$, Table 5$)$. A very high dependency between the total time for ruminating and the time necessary for consuming and ruminating $1 \mathrm{~kg}$ of $\mathrm{DM}$ was detected in lambs deprived of roughage $(\mathrm{P}<0.01$, Table 5). The total ruminating time in lambs receiving alfalfa hay, had a significant influence on the intake of DM and its ruminating $(\mathrm{P}<0.01$, Table 5).

The lambs from both groups devoted the largest percentage of their time to feeding during the morning hours, which gradually decreased by noon (Fig. 1), compensated by an increase in ruminating and time for lying down (Figs. 1 and 2). In the afternoon hours there was a tendency towards a slight increase in the time devoted to feeding. As expected, the reduction in feeding led to an increase in ruminating time. There was a linear effect between lying down and ruminating in lambs receiving alfalfa hay, significant in lambs deprived of roughage, with the results being significant at $\mathrm{P}<0.01$ (Fig. 3). Consequently, lambs ruminated mostly while lying. The lambs' time for standing up and playing was in a negative correlation with the time devoted to eating. An increased locomotor activity (standing up and playing) was established in the hours around noon, when our observations were conducted. Light was the most intensive around noon, and the temperature in the room was the highest.

\section{DISCUSSION}

The type of roughage affected intake of feed and the feeding behaviour of the animals in the experiments by Simeonov et al. (2012) and Polat et al.(2013), yet it had no influence on the number of ruminating periods in the study by Baumont et al. (1997), but when the lambs were deprived of roughage this was not confirmed in the present study, in which the differences between the two groups were significant $(\mathrm{P}<0.05$, Table 3). By itself, ruminating is a natural process in ruminants, during which bacteria have greater access to the food particles within the period of microbial fermentation (Russell and Rychlik, 2001) and the size of feed particles is broken down to such an extent that they can pass through the reticulo-omasal orifice (Welch, 1982). According to Van Soest (1994) the time devoted to ruminating is a variable, proportional to the $\mathrm{DM}$ content and the size of feed particles. This indicates that smaller feed particle size leads to less time devoted to ruminating (Perira, et al., 2013). In order to stimulate the process of ruminating, Mertens (1997) indicated that while feeding dairy cows, the minimum particle size must be $1.18 \mathrm{~mm}$, otherwise chewing time is decreased (Deswysen et al. 1987). Ruminating time in sheep is also affected by the dietary energy level (França et al., 2009). According to de Araújo Camillo et al. (2012), the high level of energy in the diet reduced the animal's chewing processes and vice versa. Such behaviour, however, was not observed in the experiment of Turino (2003). By itself, the ruminating period is described as a physiological process, which is activated after the animal is fed and calmed (Polli et al., 1996), it is then when the processing of the feed intake begins (Carvalho et al., 2004).

Depriving lambs of roughage, the time for chewing was lower $(\mathrm{P}<0.01$, Table 3$)$, the reason for this being the lower content of neutral detergent fibres (Demarquilly and Andrieu, 1988) and lignin (Jarrige et al., 1995b), as

\begin{tabular}{|c|c|c|c|c|}
\hline \multirow[t]{2}{*}{ Feeding behaviour } & \multicolumn{2}{|c|}{$\begin{array}{c}\text { Group } 1 \\
\text { Without roughage }\end{array}$} & \multicolumn{2}{|c|}{$\begin{array}{c}\text { Group } 2 \\
\text { With alfalfa hay }\end{array}$} \\
\hline & NRP & TRT & NRP & TRT \\
\hline Number of feedings per 12 hours & -0.762 & $-0.852^{\star \star}$ & 0.293 & -0.620 \\
\hline Feeding time $(\min )$ & -0.720 & -0.785 & 0.624 & -0.364 \\
\hline Time for intake of $1 \mathrm{~kg}$ of DM (min) & -0.720 & -0.785 & 0.624 & -0.364 \\
\hline Intake rate $(\mathrm{g} \mathrm{DM} / \mathrm{min})$ & 0.722 & 0.765 & -0.637 & 0.272 \\
\hline Feeding duration (g DM/min) & 0.103 & 0.168 & 0.513 & -0.120 \\
\hline Ruminating period duration (min) & 0.650 & 0.772 & -0.605 & 0.605 \\
\hline DM intake, g/ruminating (min) & $-0.941^{\star *}$ & $-0.963^{\star \star}$ & -0.269 & $-0.987^{\star \star}$ \\
\hline Total chewing time ( $\mathrm{min})$ & $0.957^{\star \star}$ & $0.964^{\star \star}$ & $0.811^{*}$ & 0.416 \\
\hline DM intake (g)/chewing duration (min) & $-0.970^{\star \star}$ & $-0.944^{\star *}$ & $-0.789^{*}$ & -0.466 \\
\hline Time necessary for intake and ruminating of $\mathrm{kg} / \mathrm{DM}(\mathrm{min})$ & $0.957^{* *}$ & $0.946^{\star *}$ & $0.811^{*}$ & -0.416 \\
\hline
\end{tabular}

NRP: Number of ruminating periods; TRT: Total ruminating time, $\min ,{ }^{*} \mathrm{P}<0.05 ;{ }^{*} \mathrm{P}<0.01$ 


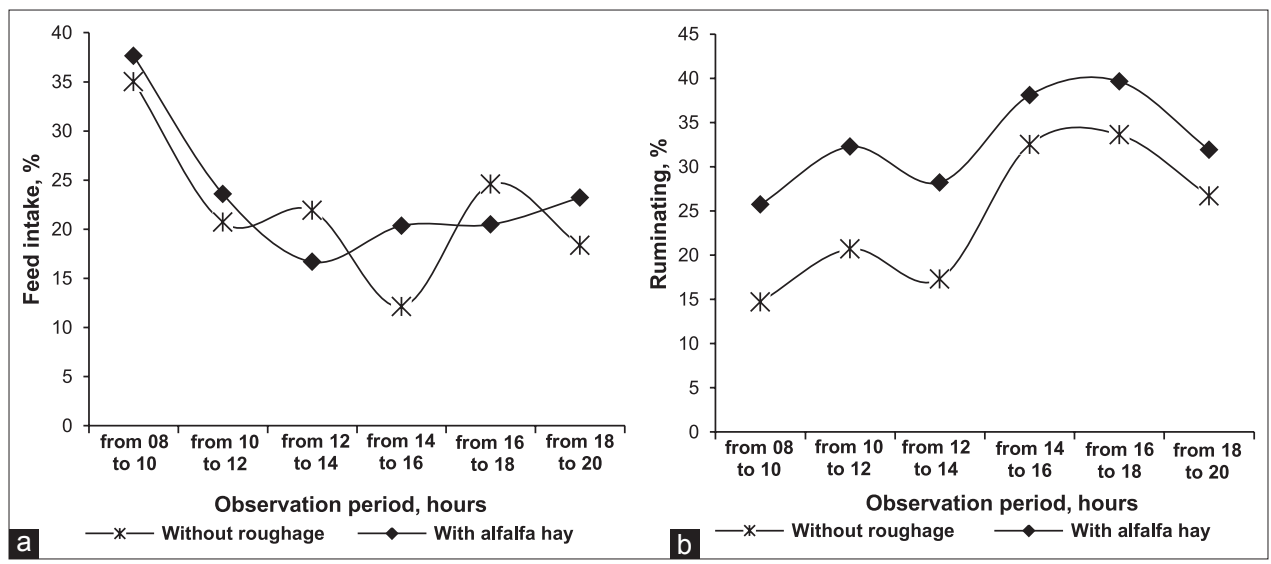

Fig 1. Feed intake (a) and ruminating (b) of lambs during the observation period.

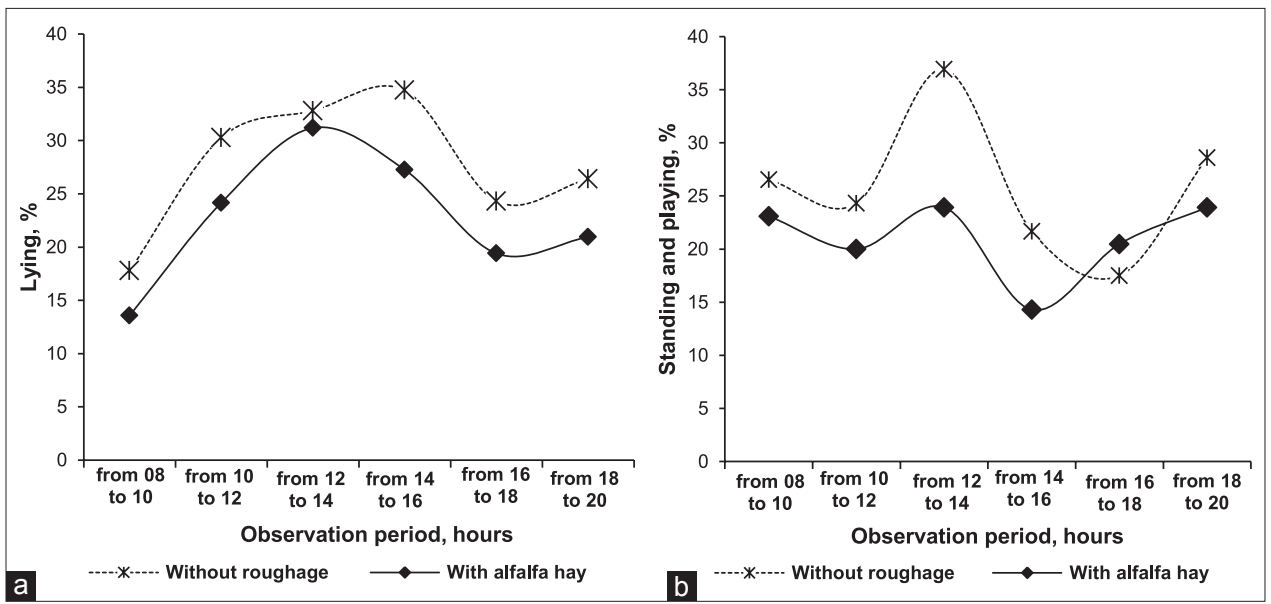

Fig 2. Lying down(a) and standing + playing (b) of the lambs during the observation period.

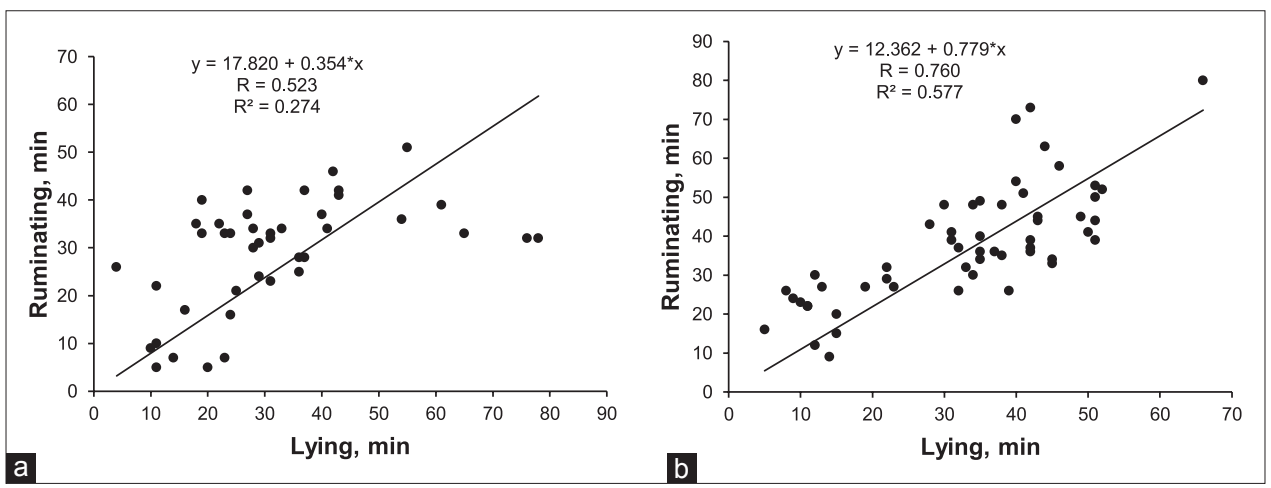

Fig 3. Dependence between time for lying down and ruminating in lambs deprived of roughage (a) and lambs receiving alfalfa hay (b).

a result of which the chewing activity of the animals ceases (Mertens 1997). Baumont (1996) reported that consumption was higher when the animals tear off the grass easier and chew it while grazing, indicating that sheep preferred and intake faster feeds with fast intake and lower fibre content (Kenney and Black, 1984). The lack of roughage is the reason the lambs chew the feed intake faster (Table 3), as supported by the study of Jarrige et al. (1995a), which indicated that when the roughage was cut into smaller pieces, the time needed for chewing was lower, as a result of which the animals invested less physical effort and had more time to rest, which reduced the animals' energy needs (Missio et al., 2010).

The number and time of feeding for lambs deprived of roughage correlated with the DM intake rate (Table 4). According to de Cruz et al. (2010) the animals devoted less time to feeding, in order to satisfy their need for food. 
The results of Fig. 1 show that for both groups of lambs, the "peak" of feeding was highest in the morning hours when the feeds were provided. Leme et al. (2013) also observed that the "peak" of feeding is at the time of providing the feeds, at which time ruminating nearly ceases. The studies by Piccione et al. (2010) and Piccione et al. (2011) confirmed our findings by establishing that the sheep's primary locomotor activity is based on the daily phototaxis, i.e. the maximum daylight illumination of the barn. During the first two hours after the provision of the feeds (from 8.00 to $10.00 \mathrm{AM}$ ), the lambs deprived of roughage devoted the highest percentage of their time to feeding, compared to the lambs receiving alfalfa hay (Fig. 1), however this trend was not preserved over the next 2 hours. One of the reasons for this was that the intake amount of concentrated feed during the primary meal increased the osmotic pressure and the volatile fatty acids (VFA), and reduced pH (Rémond et al., 1995). The other reason is that when the meal had high energy content and low amount of RF, feed intake was reduced even when the rumen was not full, as the animals satisfied their energy and protein needs (Martens, 1987). The VFA formed in the rumen reduced the food intake, but only in the short term, whereas the intake of roughage maintains a constant $\mathrm{pH}$ and leads to the formation of VFA, which retain feed intake (Faverdin et al., 1995). This indicates that the form of the ration and the dietary CF content affect feeding and ruminating (Castle et al., 1979) that the buffer capacity of the rumen depends on, as well as the amount of secreted saliva (Bartley, 1976). Considering this, it becomes clear that chewing stimulates salivation (Meakawa et al., 2002), which ensures nearly half of the bicarbonates in the rumen (Owens et al., 1998), which would probably indicate that animals which ruminate less are more susceptible to acidosis, laminitis and liver abscesses (Nocek, 1997). This, however, was not confirmed in the study by Klinger (2005), in which the feeding of calves with a diet containing $8.5 \%$ barley silage and $91.5 \%$ corn feeds provided sufficient DM for the secretion of saliva, which serves as a buffer in the rumen. The brief literature review indicated that the concerns cited in the study by Eriokson et al. (2003), namely that growing animals cannot be fed only corn feeds due to the risk of acidosis, lameness (laminitis) and liver abscess, are not substantiated. With free feeding, feed intake is highest during the first hours, described as the "primary feeding period," after which it gradually decreases until satiety occurs (Baumont et al., 2000), which was observed in our study as well (Fig. 1). During this period, the rumen was filled to the maximum, regardless of the breeding system (Thomson et al., 1985; Baumont et al., 1988). When roughage was included in the diet, the animals intake more NDF, which increases ruminating time (Ramonet et al., 1999), confirmed by our results as well (Table 3 and Fig. 1). When the animals feed intake with low crude fibre content, consumption was not affected, and at the same time the feed intake was controlled by the animals' energy needs (Araújo et al., 1998). During the noon and evening hours, the lambs receiving alfalfa hay gradually started to increase their feeding time, whereas the animals deprived of roughage exhibited a variation in feeding time with peaks in the noon and afternoon hours, which corresponds to the results reported by Keskin et al. (2010).

Providing alfalfa hay contributed to the longer time devoted to ruminating (Table 3 and Fig. 1). When only concentrated feed was intake, the lambs quickly filled their digestive tract, yet they also freed up space for new portions of feed, whereas lambs receiving hay exhibited longer ruminating time.The reason for this was that the rumen was filled with substances that are hard to digest, increasing time for ruminating (Baumont et al., 1990) or the duration of a ruminating period was affected by the meal type, more specifically the amounts of dietary CF (Van Soest, 1994). This indicated that the amount and type of CF was directly related to the duration of ruminating (Albright, 1993)and, respectively, was reduced if roughage was cut into little particles or only concentrated feed was provided, which reduced ruminating time (Van Soest, 1994). Pereira et al. (2013) reported that the times for feeding, ruminating and rest were affected by the size of the feed particles, allowing the microorganisms to colonise and degrade the feed intake faster.

In both groups, the lambs devoted a large part of their time to lying down during the noon hours (Fig. 2). According to Souza et al. (2007)the time for rest represented a reduction in physical activity, during which energy is used, and in this case energy needs were decreased (Missio et al. 2010). Demirören (2002) pointed out that sheep spent $50 \%$ of their time feeding, 40-45\% ruminating, and 5-10\% resting. According to Macedo et al. (2007)sheep devoted more time to ruminating $(54.54 \%)$, yet this is arguable because the time could be affected by the meal type (Polli et al., 1996). Our results indicated that the lambs devoted from 13.6\% to $36.9 \%$ of their time to standing and playing (Fig. 2).

The registered high level of significance between time for lying down and ruminating in lambs receiving alfalfa hay (Fig. 3). De Cruz et al. (2010) also indicated a correlation between ruminating time and time for lying down. According to Souza et al. (2007); Missio et al. (2010) this is resting time, which is related to the animals' comfort, as a result of which they have higher performance, and this, according to Silva et al. (2005), depends on the level of concentrate in the ration. 


\section{CONCLUSION}

The inclusion of roughage in the ration had a significant $(\mathrm{P}<0.01)$ influence on the time for intake and ruminating.

When lambs were deprived of roughage, they made fewer attempts to feed $(\mathrm{P}<0.01)$, which reduced total feeding time by $94.8 \min (\mathrm{P}<0.01)$.

Lambs devoted 206.7 min more to chewing when they received alfalfa hay together with their ration, which significantly $(\mathrm{P}<0.01)$ reduced DM intake and the speed of its chewing, increasing intake and ruminating time for $1 \mathrm{~kg}$ of DM by $191.5 \mathrm{~min}$.

During the light part of the day-night cycle, the lambs devoted the largest percentage of their time to ruminating, followed by lying down, feeding and standing plus playing.

\section{Author's contributions}

M.S. carried out the experiment, calculated the results and wrote the article. K.N. carried out the experiment and wrote the article. N. B. wrote the article.

\section{REFERENCES}

Albright, J. 1993. Nutrition, feeding and calves: Feeding behavior of dairy cattle. J. Dairy Sci. 76(2): 458-498.

Araújo, G., J. Silva, S. Campos, O. Campos, A. Castro, R. Signortti, S. Turco and L. Henriques. 1998. Consumo e digestibilidade total dos nutrientes de dietas contendo diferentes níveis de volumoso, em bezerros. R. Bras. Zootec. 27: 345-354.

Bartley, E. 1976. Bovine silva: Production and function of buffers in ruminant physiology and metabolism. Church and Dwight Co., Inc., New York, NY, USA.

Baumont, R. 1996. Palatability and feeding behavior in ruminant: A review. Ann. Zootech. 45: 385-400.

Baumont, R., C. Malbert and Y. Ruckebusch. 1990. Mechanical stimulation of rumen fill and alimentary behavior in sheep. Anim. Prod. 50: 123-128.

Baumont, R., J. Dulphy and J. Andrieu. 1988. Comportement alimentaire et état de réplétion du réticulo-rumen chez le mouton nourri à volonté de foin de prairie ou de Luzerne, avec accès en continu ou limité: Incidences sur le contrôle physique de l'ingestion. Reprod. Nutr. Dév. 28: 573-588.

Baumont, R., M. Jailler and J. Dulphy. 1997. Dynamic of voluntary intake, feeding behaviour and rumen function in sheep fed three contrasting types of hay. Ann. Zootech. 46: 231-244.

Baumont, R., S. Prache, M. Meuret and P. Morgand-Fehr. 2000. How forage characteristics influence behavior and intake in small ruminants: A review. In: Ledin, I. and P. Morand-Fehr, editors. Sheep and Goat Nutrition: Intake, Digestion, Quality of Products and Reangelands. CIHEAM, Zaragoza, Pp. 11-25.

Carvalho, G., A. Pires, F. Silva, C. Veloso, R. Silva, H. Silva, P. Bonomo and S. Mendonça. 2004. Comportamento ingestivo de cabras leiteiras alimentadas com farelo de cacau ou torta de dendê. Pesqui. Agropecu. Bras. 39: 919-925.

Castle, M., W. Retter and J. Waston. 1979. Silage and milk production:
Comparisons between grass silage of three different chop lengths. Grass Forage Sci. 34: 293-301.

De Araújo Camilo, D., E. Pereira, P. Pimental, R. Oliviera, M. Cândido, M. Costa and R. de Silva Aquino. 2012. Intake and feeding behavior of Morada nova lambs fed different energy levels. Ital. J. Anim. Sci. 11: 13-19.

De Cruz, R., E. Alexandrino, R. Missio, J. Neiva, J. Rastle, J. Melo, A. de Sousa Júnior and J. de Resende. 2010. Feeding behaviors of feedlot bulls fed concentrate levels and babassu mesocarp meal. R. Bras. Zootec. 41: 1727-1736.

Demarquilly, C. and J. Andreieu. 1988. Les fourrages. In: Jarrige, R., editor. Alimentation Des Bovins, Ovins et Caprins, INRA, Paris, Pp. 315-336.

Demirören, E. 2002. Hayvan Davranişlari (I. Basim). Ege Ünivrsitesi Zaraat Fakültes Yayinlati № 547, Bornova, Izmir.

Deswysen, A., W. Ellis and K. Pond. 1987. Interrelationship among voluntary intake, eating and ruminating behavior and ruminal motility of heifers fed corn silage. J. Anim. Sci. 71: 835-841.

Dulphy, J., B. Remond and M. Theriez. 1980. Ingestive behaviour and related activities in ruminants. In: Ruckebush, Y. and P. Thivend, editors. Digestive Physiology and Metablism in Ruminants. MTP Press, Lancaster, UK, Pp. 103-122.

Erickson, G., C. Milton, K. Fanning, R. Cooper, R. Swingle, J. Parrott, G. Vogel and T. Klopfenstei. 2003. Interaction between bunk management and monensin concentration on finishing performance, feeding, behavior, and ruminal metabolism during an acidosis with feedlot cattle. J. Anim. Sci. 81: 2869-2879.

Faverdin, P., R. Baumont and K. Ingvartsen. 1995. Control and prediction of feed intake in ruminants. In: Jurnet, M., E. Grenet, M. H. Farce, M. Thériez and C. Demarquilly, editors. Recent Development in the Nutrition of Herbivores, Proceedings of the IVth International Symposium on the Nutrition of Herbivores, Paris, 11-15 September 1995. INRA Editions, Paris, Pp. 95-120.

França, S., S. Gonzage Neto, E. Pimenta Filho, A. Medeiros, J. Torreão, T. Mariz and R. Costa. 2009. Comportamento ingestivo de ovelhas Morada Nova no terço inal de gestação com níveis de energia metabolizável na diet. Rev. Bras. Saúde Prod. Anim. 10: 73-84.

Huzzey, J., T. de Vries, P. Valois and M. Voneyserlingk. 2006. Stocking density and feed barrier design affect the feeding and social behavior of dairy cattle. J. Dairy Sci. 89: 126-133.

Jarrige, R., J. Dulphu, P. Faverdin, R. Baumont and C. Demarquilly. 1995a. Activités d'ingestion et de rumination. In: nutrition des Ruminants Domestiques. Jarrige, R., Y. Ruckebusch, C. Demarquilly, M. Farce and M. Journet, editors. INRA Editions, Paris, Pp. 123-181.

Jarrige, R., E. Grenet, C. Demarquilly and J. Besle. 1995b. Les constituants de l'appareil végétatif des plantes fourragères In: Nutrition des Ruminants Domestiques. Jarrige, R., Y. Ruckebusch, C. Demarquilly, M. Farce and M. Journet, editors. INRA Editions, Paris, Pp. 25-82.

Kenney, P. and J. Black. 1984. Factors affecting diet selection by sheep. I. Potential intake rateand acceptability of feed. Aust. J. Agric. Res. 35: 551-563.

Keskin, M., A. Şahin, S. Gül and O. Biçer. 2010. Effect of feed refreshing frequency on behavioural responses of Awassi lambs. Turk. J. Vet. Anim. Sci. 34: 333-338.

Keskin, M., A. Şahni, O. Biçer and S. Gül. 2004. Comparison of the behavior of Awassi lambs in cafeteria feeding system with single diet feeding system. Appl. Anim. Behav. Sci. 85: 57-64.

Klinger, S. 2005. Limit feeding a high grain barley-based diet to 
backgrounding and finishing cattle in western Canada. Graduate Studies and Research in Partial Fulfillmant of the Requirements for the Degree of Master of Science in the Department of Animal and Poultry Science, University of Saskatchewan, Saskatoon.

Lee, S., J. Hwang, Y. Yoon, W. Kwak, Y. Kim, S. Moon and B. Joen. 2008. Effects of spent mushroom substrates addition on eating behavior of growing Hanwoo. Korean J. Grass. Forage Sci. 28: 107-108.

Leme, T., E. Titto, C. Titto, A. Pereira and M. Neto. 2013. Influence of stocking density on weight gain and behavior of feedlot lambs. Small Rumin. Res. 115: 1-6.

Macedo, C., I. Mizubuti, F. Moreira, E. Pereira, E. Ribeiro, M. Rocha, B. Ramos, R. Mori, A. Pinto, T. Alves and T. Casimiro. 2007. Comportamento ingestivo de ovinos recebendo dietas som diferentes níbeis de bagaço de laranja em substituição á silage de sorgo na ração. Rev. Bras. Zootech. 36: 1910-1916.

Meakawa, M., K. Beauchemin and D. Christensen. 2002. Effect of concentrate level and feeding management on chewing activities, saliva production, and ruminal $\mathrm{pH}$ of lactating dairy cows. J. Dairy Sci. 85: 1165-1175.

Mertens, D. 1987. Predicting intake and digestibility using mathematic models of ruminal function. J. Anim. Sci. 64: 1548-1558.

Mertens, D. 1997. Creating a system for meeting the fiber requirements of dairy cows. J. Dairy Sci. 80: 1463-1481.

Missio, R., I. Brondani, D. Filho, M. de Silveira, L. de Silva Freitas and J. Restle. 2010. Comportamento ingestivo de tourinhos terminados em confinamento alimentados com diferentes níveis de concentrado na dieta. Rev. Bras. Zootech. 7: 1571-1578.

Nocek, J. 1997. Bovine Acidosis: Implications on laminitis. J. Dairy Sci. 80: 1005-1028.

Norouzian, M. and M. Vatandoost. 2011. Effect of feeding buckets number per pen on performance and behavior indicators of lambs. Iran. J. Appl. Sci. 1: 273-277.

O'connell, N.,V. Beattie and R. Weatherup. 2004. Influence of group size during the post-weaning period on the performance and behavior of pigs. Livest. Prod. Sci. 86: 225-232.

Owens, F., D. Secrist, W. Hill and D. Gill. 1998. Acidosis in cattle: A review. J. Anim. Sci. 76: 275-286.

Penning, P., A. Rook and R. Orr. 1991. Patterns of ingestive behavior of sheep continuously stocked on monocultures of ryegrass or white clover. Appl. Anim. Behav. Sci. 31: 237-250.

Pereira, T., M. Pereira, P. Almeida, C. Pereira, A. dos Santos and E. dos Santos. 2013. Mesquite pod meal in diets for Santa Inês sheep: Ingestive behavior. Acta Sci. 35: 201-207.

Piccione, G., C. Giannetto, S. Marafioti, S. Casella, A. Assenza and F. Fazio. 2011. Effect of different farming management on daily totallocomotor activity in sheep. J. Vet. Behav. 6: 243-247.

Piccione, G., C. Giannetto, S. Casella and G. Caola. 2010. Daily locomotor activity in five domestic animals. Anim. Biol. 60: 15-24.

Pinto, A., J. Marques, J. Abrahão, W. Nascimento, M. Costa and S. e Lugão. 2010. Comportmento e eficiêcia ingestiva de tourinhos mestiços confinados com três dietas diferentes. Arch. Zootec. 59: 427-434.
Pires, M., D. Vilela and M. Alvim. 2001. Comportamento alimentar de vacas holandesas em sistemas de pastagem ou em confinamento. Instrução Técnica Para o Produtor De Leite: EMBRAPA, Pp. 1-2.

Polat, E., B. Coskun, E. Gurbuz and T. Balevi. 2013. The effects of roughage type on the daily patterns of feed intake and eating behavior in young sheep. Rev. Méd. Vét. 11: 503-510.

Polli, V., J. Restle, D. Senna and S. Alimeida. 1996. Aspectos relativos á ruminação de bovinos e bubalinos em regime de confinamento. Rev. Bras. Zootecn. 25: 987-993.

Ramonet, Y., M. Meunier-Saluan and J. Dourmad, 1999. High-fiber diets in pregnant sows: Digestible utilization and effects on the behavior of the animals. J. Anim. Sci. 77: 591-599.

Rémond, B., H. Brugère, C. Poncet and R. Baumont. 1995. Le contenu du réticoulo-rumen. In: Jarrige, R., Y. Ruckebusch, C. Demarquilly, M. H. Farce, M. Journet editors. Nutrition Des Ruminants Deomestiques. Ingestion et Digestion. INRA Editions, Versailles, Pp. 123-181.

Russell, J. and J. Rychlik. 2001. Factors that alter the rumen microbial ecelogy. Science. 292: 1119-1122.

Shabi, Z., I. Bruckental, S. Zamwell, H. Tagri and A. Arieli. 1999. Effects of extrusion of grain and feeding frequency on rumen fermentation, nutrient digestibility and milk yield and composition in dairy cows. J. Dairy Sci. 82: 1252-1260.

Silva, R., F. Silva, G. Carvalho, I. Franco, C. Veloso, M. Chaves, P. Bonomo, I. Prado and V. Almeda. 2005. Comportamento ingestivo de novilhas mestiças de Holandês $\times$ Zebu confinadas. Arch. Zootec. 54: 75-85.

Simonov, M., K. Nedelkov, N. Todorov. 2015. Influence of roughage in the rations of early weaned lambs. J. Dairy Vet. Anim. Res. 2: 0042. DOI: 10.15406/jdvar.2015.02.00042.

Simeonov, M., I. Stoycheva and A. Kirilov. 2012. Feeding behaviour of lambs. J. Mt. Agric. Balkans. 15: 508-517.

Souza, S., L. Ítavo, J. Rímoli, C. Ítavo and A. Dias. 2007. Comportamento ingestivo diurno de bovinos em confinamento e em pastagens. Arch. Zootec. 56: 67-70.

Statistica. 2006. Statistica for Windows, StatSoft Inc., Tulsa, OK, USA.

Thomson, B., G. Cruickschank, D. Poppi and A. Sykes. 1985. Diurnal patterns of rumen fill in grazing sheep. Proc. NZ Soc. Anim. Prod. 45: 117-120.

Titto, E., C. Titto, E. Gatto, C. Noronha, G. Mourão, J. Filho and A. Pereira. 2010. Reactivity of Nellore steers in two feedlot housing systems and its relationship with plasmatic cortisol. Livest. Sci. 129: 146-150.

Turino, V. 2003. Substituição da fibra em detergent neutro (FDN) do bagaço de cana-de-açúcar in natura pela FDn de casca de soja em dietas contendo alta proporção de concentrados para cordeiros confinados. Degree Dissertion, Universidade de São Paulo, Brazil.

Van Soest, P. 1994. Nutritional Ecology of the Ruminant, 2nd ed. Cornell University Press New York.

Welch, J. 1982. Rumination, particle size and passage from the rumen. J. Anim. Sci. 54: 885-894. 